\title{
The risk factors, consequences, treatment, and importance of gestational depression
}

\section{Gebelik depresyonu; risk faktörleri, sonuçları, tedavisi ve önemi}

\author{
Elif Akkaş Yılmaz¹, Çağrı Gülümser² \\ 1Sami Ulus Women and Children's Diseases Training and Research Hospital, Clinic of Obstetrics and Gynecology, Ankara, Turkey \\ ${ }^{2}$ Başkent University Faculty of Medicine, Department of Obstetrics and Gynecology, Ankara, Turkey
}

\begin{abstract}
Nowadays, mental problems have become an important health issue, the most frequent of which in pregnancy is depression. Gestational depression is known to increase gestational complications and negatively affect maternal and fetal health. The frequency of gestational depression and depressive symptoms are $10-30 \%$. Risk factors vary according to genetic, psychologic, environmental, social, and biologic factors. Maternal morbidity and mortality rates increase in pregnant women who do not receive treatment, obstetric complications and negative fetal consequences are seen, and the incidence of postpartum depression increases. Due to all these important consequences, healthcare providers who manage pregnant women should be informed about the frequency, symptoms, and screening methods of postpartum depression, the significance of the consequences of undiagnosed and untreated depression on the health of mother and baby, and the importance of early diagnosis. Pregnant women who are at risk should be screened and detected, and directed to related centers. In this review, we briefly review the definition of gestational depression, its frequency, risk factors, complications, screening, treatments, and the procedures that need to be performed the diagnostic process. J Turk Soc Obstet Gynecol 2015;2:102-13
\end{abstract}

Key Words: Pregnancy, depression, complications, risk factors, treatment

\section{Özet}

Günümüzde ruhsal sorunlar önemli bir halk sağllğı sorunu haline gelmiş olup, bunlar içerisinde gebelikte en sik görüleni depresyondur. Gebelikte yaşanan depresyonun, hem gebelik komplikasyonlarını arttırdığı hem de annenin ve fetüsün sağlı̆̆ını olumsuz etkilediği bilinmektedir. Gebelikte depresyon ve depresif semptom görülme sıklı̆̆ \%10-30 arasında değişmektedir. Risk faktörleri kültürler arasında farklılık göstermekte olup, genetik, psikolojik, çevresel, sosyal ve biyolojik faktörlerin etkileri üzerinde durulmaktadır. Tedavi almayan gebelerde, maternal morbidite ve mortalite hızı artmakta, obstetrik komplikasyonlar ve olumsuz fetal sonuçlar görülmekte, postpartum depresyon insidansında artış saptanmaktadır. Tüm bu önemli sonuçları nedeniyle, gebeleri takip eden sağlı personeli, gebelik ve doğum sonrası depresyonun sıklı̆̆l, semptomları ve tarama yöntemleri, tanı almayan veya tedavi edilmeyen depresyonun anne ve bebek sağlığı üzerindeki etkileri ve erken tanının önemi hakkında bilgilendirilmelidir. Risk altındaki gebeler saptanmalı ve taramalar sonucunda riskli bulunan gebeler ilgili merkezlere yönlendirilebilmelidir. Bu amaçla bu yazıda, gebelikte depresyonun tanımı, sıklığı, risk faktörleri, komplikasyonları, taraması, tedavisi ve bu süreçte yapılması gerekenler kısaca gözden geçirilmiştir. J Turk Soc Obstet Gynecol 2015;2:102-13

Anahtar Kelimeler: Gebelik, depresyon, komplikasyon, risk faktörü, tedavi

\section{Introduction}

Today, the incidence of mental problems are significantly increased, and have become both an individual and a public issue. Of all the mental disorders, the most frequent and the one that carries the greatest burden is depression. Depression is an illness that decreases onereaquality of life by making functions, creativity, happiness, and satisfaction fade away and reduces the capacity for work. Its frequency, chronicity, high rates of recurrence, and suicide incidence makes it an important health issue and the third most important disease in the world in terms of its burden. Depression is ranked as the eighth greatest healthcare burden in low-income countries; however, it is number one in countries that have average and higher incomes $(1,2)$. Depression is the most frequent of all mental disorders in the gestational period. In past years, the gestational period was known to bring a sensation of well-being and this was thought to protect against mental disorders. However, today it has been recognized that gestational depression has been missed because the physiologic changes and symptoms seen in depression are similar to those in the gestational and postpartum period (e.g. sleeping habits, appetite, weight changes, and fatigue)(3). According to World Health Organizationes, pression hurden ncrea(4), 1 in 3-5 pregnant women in developing countries, and 1 in 10 pregnant women in developed countries have severe mental problems

Address for Correspondence/Yazışma Adresi: Çağnı Gülümser, MD,

Başkent University Faculty of Medicine, Department of Obstetrics and Gynecology, Ankara, Turkey

Phone: +90 5307837593 E-mail: cagrigulumser@yahoo.com

Received /Geliş Tarihi : 10.09.2014

Accepted/Kabul Tarihi : 07.12.2014 
either during gestation or in the postpartum period. Depression in pregnancy is the most important risk factor for postpartum complications and fetal-neonatal problems, and is more frequent than in the postpartum period. Gestational depression has become an important issue. Despite it being such an important health issue, the development of depression during pregnancy is not being detected and consequently women are not receiving proper treatment because there is still no screening program and healthcare providers are not yet sufficiently knowledgeable. Here, we briefly review, the definition of gestational depression, its frequency, risk factors, symptoms, risks for mother and baby, screening, and treatment.

\section{The prevalence of gestational depression in the world and in turkey}

According to the literature, the frequency of gestational depression and depressive symptoms is between 10-30\%(5-9). In the study of Bödecs et al. performed in $\operatorname{Hungary}(10)$, the prevalence of gestational depression was found to be $18 \%$, the result of the Marcus et al. study in the United States of America was $20 \%$, and Kurki et al. reported $30 \%$ in Finland(11,12). In the studies in our country, Turkey, the gestational depression prevalence has been reported to be between 27.9-33.1\%(13-17). As these numbers are higher than the values of the world, it is estimated that factors in the lives of pregnant women in our country affect the prevalence and intensity of the gestational depression (e.g. teenage pregnancies, frequent pregnancies, economic problems, low education levels, violence in the family, crowded families)(14,15).

\section{Risk factors of gestationel depression}

As shown in Table 1, the potential risk factors of gestational depression should be considered through different perspectives. In the literature, the affects of genetic, psychologic, environmental, social and biologic factors are considered. History of depression, history of depression in the family, marital problems, lack of partner, lack of social support, negative experiences, violence, lower social and economic levels, poor obstetric history (abortus, death), unwilling pregnancies, very early or late pregnancies, and low education levels form the risk factors and these vary according to cultures(6,7,18-20). In a randomized study conducted by Leigh et al. in Australia on 367 pregnant women(21), depression risk was found to be high in those who lacked self-respect, were anxious in pregnancy, lacked social support, had lower incomes, and those who experienced a significant trauma. In the study of Figueiredo et al. performed in Portugal, teenaged pregnant girls showed significantly more depressive symptoms during their pregnancies and postpartum periods(22). Those who receive antidepressants are under the risk of depression and its recurrence when they terminate their medication after getting pregnant; the first 8 weeks after termination of medication carry the greatest risk. Cohen et al. found that relapses of depression occurred in $43 \%$ women who had had a major attack of depression, $26 \%$ of those who continued their medication, and $68 \%$ of those who terminated their medication depression(23). In most cases, miscommunication, unwilling pregnancies, and marital problems are more frequent. All complications seen in pregnancy and all the medical problems that make a pregnancy risky have the potential to cause psychiatric symptoms. The incidence of anxiety and depression is higher in the gestationaland postpartum period in pregnant women who have medical problems like hypertension and diabetes, and women who have obstetric problems like preeclampsia, risk of early labor, poli/ oligohidramnios, and intrauterine growth retardation when compared with those without medical problems $(24,25)$.

\section{Findings and symptoms of gestational depression}

It can frequently be hard to diagnose gestational depression because the findings and symptoms of depression in pregnant women are so similar to the physiologic changes and symptoms during pregnancy. The major findings and symptoms of depressed mood during pregnancies are; changes in sleep habits and appetite, pain, fluctuation in sensations, abnormal fatigue, lack of libido and concentration, and anxiety and fears about delivery. Even if these symptoms of depression cannot be separated from the symptoms of general depression, somatic symptoms like nausea, stomach ache, tachypnea, hyperpnoea, headache, gastrointestinal symptoms, tachycardia, and lightheadedness are significantly more likely to be seen, hyperactive physical symptoms have to be important.

\section{The affects and consequences od the gestational depression}

The consequences of gestational depression can be seen in Table 2, grouped as maternal, fetal, and childhood originated.

Table 1. Risk factors for antepartum depression

Previous depression episodes

Family history of depression

Discord/uneasiness within the family

Lack of partner

Lack of social support

Negative life experiences

Domestic violence

Unplanned pregnancy

Demographic characteristics

Low socio-economic status

Early/advanced maternal age

Low educational level

Unemployment

Poor obstetric history (abortus/history of still birth) 
Maternal morbidity, mortality, and suicide attempt rates increase in women who have depression during pregnancy and do not receive treatment. Gestational depression affects both the physical and mental health of women by decreasing their self-hygiene and increasing gestational complications, which negatively effect the health of the fetus. Preeclampsia and eclampsia, early-onset labor, babies with lower weight, and APGAR have been found to be more related to the depression during pregnancy $(12,26,27)$. If no is action taken during pregnancy and depression continues, the risk increases in the babies and children. These negative effects present as problems in bond development between babies and mothers, growth retardations, development of motor and linguistic skills, and increased risk in gastrointestinal and lower respiratory infections(28-30). Sensory and cognitive problems are known to develop in such children in later years $(31,32)$. Many studies have proven that gestational depression is the most important risk factor of postpartum depression and depression continues during the postpartum period in $50 \%$ of women who had depression during their pregnancies $(21,33,34)$.

\section{Effects of gestational depression on pregnant women}

Gestational depression decreases mothers' self-hygiene, which can harm cognitive functions in terms of decision-making ability, this situation may be correlated with lack of concentration during pregnancy and use addictive substances. Many studies have shown that women with gestational depression use tobacco and alcohol and addictive substances during their pregnancies $(35,36)$. In the study of Zuckerman et al., depression in pregnancy was highly correlated with tobacco, alcohol, and cocaine use (37). Pregnant women with symptoms of depression are more likely to miss their screenings, tend to receive less medical help, and have less pre-delivery help. These patients

Table 2. Outcomes of antenatal depression

Maternal outcomes

Hypertensive disorders of pregnancy (Preeclampsia-Eclampsia)

Preterm birth

Postpartum depression

Fetal outcomes

Baby small for gestational age

Low birth weight

Low APGAR scores

Childhood outcomes

Growth retardation

Delay in motor and language development

Increased risk of gastrointestinal and lower respiratory tract infections

Cognitive-behavioral-emotional problems generally have nutritional and sleeping problems and gain less weight than the normal because of their loss of appetite. It is known that those who have depression have decreased social function, become introvert, and have fears about becoming parents. In patients for whom depression continues after delivery, provision of reduced care, increased anxiety, and thoughts about harming offspring can be seen. Severe depression may lead to self-harm, an increased risk of showing brutal actions, and may cause suicide(38-41). Hesse et al. showed that $5 \%$ of patients who had depression during pregnancies and received no treatment had attempted suicide ${ }^{(42)}$. Of the causes of death directly connected to pregnancy, suicide accounts for $2.4 \%$ of deaths related to pregnancy, and 3.2\% of maternal deaths.

\section{Screening of gestational depression}

It is vital to diagnose depression in pregnant women early because it is important to give medication to decrease longterm negative consequences. The American College of Obstetricians and Gynecologists Committee advises that all women, regardless of social status, education level, and ethnicity, should be screened at least once every trimester for mental disorders(43). The screening should be done using short, reliable, valid methods that have high sensitivity and low false positive rates. The commonly-used methods for the screening of depression during pregnancy include the Patient Health Questionnaire, Beck Depression Inventory, Center for Epidemiologic Studies Depression Scale, Two-Sentence test, and the Edinburgh Postpartum Depression Scale(44-46). Supplements 1-4 demonstrate all screening tools mentioned above for gestational depression.

\section{Treatment approaches in gestational depression}

The treatment of gestational depression is becoming an important issue for researchers and physicians. In the last few years, physicianss studies have mostly been about concerns of medications used in the treatment of depression and how they effect the fetus; however, now it is understood that the real problem is depression without medication. Today, the view is that gestational depression should be treated because of its negative consequences on both mother and fetus. There are 3 problems that clinicians have to solve when they meet a mother in depression:

Women who become pregnant while using antidepressants and continue using them for some time without being aware that they are now pregnant: according to todaya mother in dethis situation carries low risk; however, a conversation with the mother and relatives should take place to provide information about the risks and a decision about the pregnancy has to be made.

Depression began before pregnancy and is ongoing or the depression occurred during pregnancy: For women who have not been given medication, if psychotherapy cannot be undertaken or is insufficient, treatment especially with an SSRI 
is the most accepted approach that is accepted the most because the risk of damage to mother and baby is high.

Babies with possible withdrawal symptoms whose mother had medical treatment during pregnancy: Most of these symptoms can be cured by general support but it is important for physicians to be aware of the situation and closely observe the baby. Patients and their relatives have to be involved in all decision processes. It is extremely difficult to form a treatment method that can be applied to all pregnant women. It is the responsibility of the physician to evaluate all cases on an individual basis and form a treatment strategy for the sake of mother and child.

\section{Psychotherapy}

Psychotherapies are the first choice in the treatment of depression because of the possible adverse effects of medical therapy, especially in mild and moderate depression (for patients who do not have recurrent depressive episodes, severe weight loss, suicide attempts and who are not inpatients) (Grade 2B). Short-term physiotherapies in particular have been found to be effective and they are being used more frequently. Interpersonal and cognitive behavioral therapies are reported to be efficient for mild and moderate depression.

\section{Interpersonel psychotherapies}

Interpersonal physiotherapies are short therapies that focus on interpersonal problems that aim to decrease depressive symptoms and fix interpersonal functions. They also serve to help form social support systems that will help to cope with the stress. Acute interpersonal problems can be discussed in such an environment; cognitive processes and previous relations are not addressed in this way. Treatment time is between 12-20 weeks, once a week(47-49). It has been shown to be effective for both gestational and postpartum depression. On the study reported on 120 women who had major depression and had given birth the women were separated into 2 randomized groups, one of which received interpersonal psychotherapy for 12 weeks(50). The authors found a significant difference in terms of remission for the group that received physiotherapy (37.5\%) compared with the con-treatment group (13.7\%).

Table 3. Treatment of antepartum depression

\section{Cognitive behavioral therapy}

Cognitive behavioral therapy is one of the most commonlyused psychotherapy methods of the world, and is effective for most mental disorders. This therapy aims to fix depression by modifying schemes formed by cognitive distortions, which effect emotions and result in depression. Approximately 12 sessions are needed for depression.

\section{Medical treatments}

Medical treatment should be considered when psychotherapies are difficult to perform or become unsuccessful, in cases of moderate depression, history of severe depression, positive outcomes of medical treatments, and the possibility of the mothern, positive outcomes high. Even though the reliability of these medications not yet proved due to the difficulty of performing studies on pregnant women, according to the outcomes of the actual medications, there is no major malformations affect in fetuses. Before starting a medication in pregnant women, risks for a developing fetus must be evaluated in terms of malformations of organs, teratogenesis, neonatal withdrawal and toxicity syndromes, and long-term behavioral effects. Before initiating a medication, the potential harms and benefits and severity of depression should be considered(51,52). The treatment of gestational depression is summarized in Table 3.

SSRIs: SSRIs are the first-choice medications according to the literature (Grade 2B). They are a group C medication for pregnant women. The first medication of this group is fluoxetine and it is the most well known for use in pregnancy. No evidence of teratogenity in the children women who used fluoxetine, fluvoxamine, sertraline, and paroxetine during their pregnancies has been reported in the literature; however, some medical problems have occurred(53,54). According to some studies, early onset of labor and lower weight of the baby, lower APGAR scores and persistent pulmonary hypertension in the neonate have occurred when used in the late periods of pregnancy $(53,54)$. When compared with other antidepressants, paroxetine was reported to lead to more congenital malformations, especially cardiac abnormalities, although the studies may have had conflictions; there is no
Mild-moderate depression

Psychotherapy

Interpersonal psychotherapy

Cognitive behavioral psychotherapy

Severe depression

Failure in psychotherapy

Recurrent depressive Episodes

History of severe depression

History of hospital admission

Severe weight loss

Suicide attempts

Unresponsiveness to SSRI/Venlafaxine/Bupropion
Medical treatment

SSRI/Venlafaxine/Bupropion 
definite conclusion(55-57). Neonates who are exposed to SSRIs in the third trimester can display symptoms of withdrawal (irritability, hypotonia, mild respiratory problems, and eating and sleeping disorders) but these can be easily treated with general support. Still, for the initial therapy, sertraline is the most recommended; citalopram is also an appropriate alternative.

For women with severe depression who do not respond to SSRIs, venlafaxine and bupropion should be chosen instead of other antidepressants (Grade 2C). In addition, electroconvulsive therapy can be considered.

Tricyclic Antidepressants: Even though there are differences between studies in the literature, the general consensus is that there is no increase in the risk of congenital malformations in neonates who are exposed to tricyclic antidepressants in the first trimester when compared with the general population. Functional intestinal obstruction and urinary retention can be seen in neonates due to anti-cholinergic adverse effects with all the tricyclic antidepressants. especially with clomipramine(58-64)

Electroconvulsive Therapy (ECT): Electroconvulsive therapy is recommended in the event that patients do not respond to psychotherapy and recurrent medical treatments (3-5 times). Especially in the major depression of the pregnant women, it is accepted as fast, reliable, and safe. In the literature, although some studies have reported fetal death, decrease in fetal heart rate, increase in uterine contractions, and early onset of labor, ECT is accepted today as an effective way to treat severe depression during pregnancy and its risks are minimal for mother and fetus(65-67).

\section{Results}

Mother and child health is one of the most important subjects of the World Health Oraganization' a expectations for 2015 and for the Millennium Development Plans. In the past, even if the focus was only on the physical health of mother and child and mental health was ignored, today, the findings show that their physical and mental health cannot be separated and progress can be made only with them being combined. For this reason, knowing the risk factors of gestational and postpartum depression, and closely screening those at risk are important. It should be remembered that early diagnosis and treatment has positive effects on the physical and mental health of the mother and baby and their relationship(68).

Gestational depression is as important as postpartum depression and should be diagnosed and treated early; however, it has not been considered as an important issue. Despite the many studies on gestational depression, only recently has the issue become important. Pregnancy is difficult period in terms of mental status and as yet, no standard for psychiatric support exists in Turkey even though gestational depression and anxiety are acknowledged to be very frequent, and importance is given to preterm care. Women with gestational depression are often not examined and consequently go untreated. When the effects on baby and mother are considered, women who are at risk of depression and anxiety must be identified early in healthcare centers, and should receive follow-up and treatment as required. During pregnancy, women should undergo the necessary assessments to maintain their physical and mental well-being, and these assessments ought to become a part of regular follow-ups. Healthcare providers who manage pregnant women should be educated about the frequency, symptoms, and screening methods of gestational and postpartum depression, the effects on mother and babyhs health if depression goes undiagnosed and untreated. In addition, clinicians must be informed about the risk factors of postpartum depression and the importance of watching closely for those exposed to these risks. Finally, depressionscreening programs should be formed in Turkey in which pregnant women are seen by professional groups in order to detect and prevent mental disorders, like they are in developed countries. Those who are detected as being at risk as a result of these screening programs should be referred for necessary treatment at appropriate centers.

Concept: Elif Yılmaz, Çağrı Gülümser

Design: Elif Yllmaz, Çağrı Gülümser

Data Collection or Processing: Elif Yılmaz, Çağrı Gülümser Analysis or Interpretation: Elif Yılmaz, Çağrı Gülümser

Literature Search: Elif Yılmaz, Çağrı Gülümser

Writing: Elif Yılmaz, Çağrı Gülümser

Peer-review: External and Internal peer-reviewed.

Conflict of Interest: No conflict of interest was declared by the authors.

Financial Disclosure: The authors declared that this study has received no financial support.

\section{References}

1. World Health Organisation (2001). Geneva: WHO. The world health report 2001. Mental Health: New understanding, new hope. Erişim:(http://www.who.int/whr/2001/en/whr01_ch2_en.pdf). Erişim Tarihi:02.02.2013

2. World Health Organisation (2008). The Global Burden of Disease: 2004update. Erişim:(http://www.who.int/healthinfo/global_ burden_disease/GBD_report_2004update_part4.pdf). Erişim tarihi: 02.02.2013

3. Cohen LS, Sichel DA, Faraone SV, Robertson LM, Dimmock JA, Rosenbaum JF. Course of panic disorder during pregnancy and the puerperium: a preliminary study. Biol Psychiatry 1996;39:950-4.

4. World Health Organisation (2008). Geneva: WHO. Maternal mental health and child health and development in low and middle income countries. Erişim: (http://www.who.int/mental_health/ prevention/suicide/mmh_jan08_meeting_report.pdf). Erişim Tarihi: 09.02.2013.

5. Da Costa D, Larouche J, Dritsa M, Brender W. Psychosocial correlates of prepartum and postpartum depressed mood. J Affect Disord 2000;59:31-40.

6. Bowen A, Muhajarine N. Prevalance of antenatal depression in women enrolled in an outreach program in Canada. J Obstet Gynecol Neonatal Nurs 2006;35:491-8 
7. Pereira PK, Lovisi GM, Pilowsky DL, Lima LA, Legay LF. Depression during pregnancy: prevalence and risk factors among women attending a public health clinic in Rio de Janeiro, Brazil. Cad Saude Publica 2009;25:2725-36.

8. Leung BM, Kaplan BJ. Perinatal depression: prevalence, risks, and the nutrition link-a review of the literature. J Am Diet Assoc 2009;109:1566-75.

9. Shah SM, Bowen A, Afridi I, Nowshad G, Muhajarine N. Prevalance of antenatal depression: comparison between Pakistani and Canadian women. J Pak Med Assoc 2001;61:242-6.

10. Bödecs T, Horvath B, Kovacs L, Diffellne Nemeth M, Sandor J. Prevalence of depression and anxiety in early pregnancy on a population based Hungarian sample. Orv Hetil 2009;150:1888-93.

11. Marcus SM, Flynn HA, Blow FC, Barry KL. Depressive symptoms among pregnant women screened in obstetrics settings. J Womens Health (Larchmt) 2003;12:373-80.

12. Kurki T, Hiilesmaa V, Raitasalo R, Mattila H, Ylikorkala O. Depression and anxiety in early pregnancy and risk for preeclampsia. Obstet Gynecol 2000;95:487-90.

13. Çalıskan D, Oncu B, Kose K, Ocaktan ME, Ozdemir O. Depression scores and associated factors in pregnant and non-pregnant women: a community-based study in Turkey. J Psychosom Obstet Gynaecol 2007;28:195-200

14. Golbasi Z, Kelleci M, Kisacik G, Cetin A. Prevalance and correlates of depression in pregnancy among Turkish women. Matern Child Health J 2010;14:485-91.

15. Karaçam Z, Ancel G. Depression, anxiety and influencing factors in pregnancy: a study in a Turkish population. Midwifery 2009;25:344-56.

16. Ocaktan ME, Çalışkan D, Öncü B, Özdemir O, Köse K. Antepartum and postpartum depression in a primary health care center area. Ankara Üniversitesi Tıp Fakültesi Mecmuası 2006;59:151-7.

17. Senturk V, Abas M, Berksun O, Stewart R. Social support and antenatal depression in extended and nuclear family environments in Turkey: a cross-sectional survey. BMC Psychiatry 2011;11:48.

18. Lau Y, Keung DW. Correlates of depressive symptomatology during the second trimester of pregnancy among Hong Kong Chinese. Soc Sci Med 2007;64:1802-11.

19. Bowen A, Stewart N, Baetz M, Muharajine N. Antenatal depression in socially high-risk women in Canada. J Epidemiol Community Health 2009;63:414-6.

20. Kheirabadi GR, Maracy MR. Perinatal depression in a cohort study on Iranian women. J Res Med Sci 2010;15:41-9.

21. Leigh B, Milgrom J. Risk factors for antenatal depression, postnatal depression and parenting stress. BMC Psychiatry 2008;8:24.

22. Figueiredo B, Pacheo A, Costa R. Depression during pregnancy and the postpartum period in adolescent and adult Portuguese mothers. Arch Womens Ment Health 2007; 10:103-9.

23. Cohen LS, Altshuler LL, Harlow BL, Nonacs R, Newport DJ, Viguera AC, et al. Relapse of major depression during pregnancy in women who maintain or discontinue antidepressant treatment. JAMA 2006;295:499-507.

24. Benute GR, Nomura RM, Reis JS, Fraguas Junior R, Lucia MC, Zugaib M. Depression during pregnancy in women with a medical disorder: risk factors and perinatal outcomes. Clinics 2010;65:1127-31.

25. King NM, Chambers J, O'Donnell K, Jayaweera SR, Williamson C, Glover VA. Anxiety, depression and saliva cortisol in women with a medical disorder during pregnancy. Arch Womens Ment. Health 2010;13:339-45.

26. Diego MA, Field T, Hernandez-Reif M, Schanberg S, Kuhn C, Gonzalez-Quintere VH. Prenatal depression restricts fetal growth. Early Hum Dev 2009;85:65-70.
27. Field T. Prenatal depression effects on early development: a review. Infant Behav Dev 2011;34:1-14.

28. Rahman A, Igbal Z, Bunn J, Lovel H, Harrington R. Impact of maternal depression on infant nutritional status and ilness: a cohort study. Arch Gen Psychiatry 2004;61:946-52.

29. Ban L, Gibson JE, West J, Tata LJ. Association between perinatal depression in mothers and the risk of childhood infections in offspring: a population-based cohort study. BMC Public Health 2010;10:799.

30. Surkan PJ, Kennedy CE, Hurley KM, Black MM. Maternal depression and early childhood growth in developing countries: systematic review and meta-analysis. Bull World Health Organ 2011;89:608-15.

31. Field T. Maternal depression effects on infants and early interventions. Prev Med 1998;27:200-3.

32. Onunaku N. Improving Maternal and Infant Mental Health: Focus on Maternal Depression. Los Angeles CA: National Center for Infant and Early Childhood Health Policy at UCLA; 2005.

33. Beck CT. Predictors of postpartum depression: an update. Nurs Res 2001;50:275-85

34. Silva R, Jansen K, Souza L, Quevedo L, Barbosa L, Moraes I, et al. Sociodemographic risk factors of perinatal depression: a cohort study in the public health care system. Rev Bras Psiquiatr 2012;34:143-8.

35. Flynn HA, Walton MA, Chermack ST, Cunningham RM, Marcus SM. Brief detection and co-occurrence of violence, depression and alcohol risk in prenatal care settings. Arch Womens Ment Health 2007;10:155-61.

36. Goodwin RD, Keyes K, Simuro N. Mental disorders and nicotine dependence among pregnant women in the United States. Obstte Gynecol 2007;109:875-83.

37. Zuckerman B, Amaro H, Bauchner H, Cabral H. Depressive symptoms during pregnancy: relationship to poor health behaviors. Am J Obstet Gynecol 1989;160:1107-11.

38. Bonari L, Bennett H, Einarson A, Koren G. Risks of untreated depression during pregnancy. Can Fam Physician 2004;50:37-9.

39. Comtois KA, Schiff MA, Grossman DC. Psychiatric risk factors associated with postpartum suicide attempt in Washington State, 1992-2001. Am J Obstet Gynecol 2008;199:120.

40. Gavin AR, Tabb KM, Melville JL, Guo Y, Katon W. Prevalence and correlates of suicidal ideation during pregnancy. Arch Womens Ment Health 2011;14:239-46.

41. da Silva RA, da Costa Ores L, Jansen K, da Silva Moraes IG, de Mattos Souza LD, Magahlaes P, et al. Suicidality and associated factors in pregnant women in Brazil. Communtiy Ment Health J 2012;48:392-5.

42. Hasser C, Brizendine L, Spielvogel A. SSRI use during pregnancy. Do antidepressants benefits outweigh the risks? Current Psychiatry 2006;5:31-40.

43. American College of Obstetricians and Gynecologists Committee on Health Care for Undeserved Women. ACOG Committee Opinion No. 343: psychosocial risk factors: perinatal screening and intervention. Obstet Gynecol 2006;108:469-77.

44. Whooley MA, Avins AL, Mıranda J, Browner WS. Case-finding instruments for depression. Two questions are as good as many. J Gen Intern Med 1997;12:439-45.

45. No authors listed. Screening for depression: recommendations and rationale. Am Fam Physician 2002;66:647-50.

46. Breedlove G, Fryzelka, D. Depression screening during pregnancy. J Midwifery Womens Health 2011;56:18-25.

47. Spinelli MG. Interpersonal psychotherapy for depresse antepartum women: a pilot study. Am J Psychiatry 1997;154:1028-30.

48. Spinelli MG, Endicott J. Controlled clinical trial of interpersonal psychotherapy versus parenting education program for depressed pregnant women. Am J Psychiatry 2003; 160:555-62. 
49. Grigoriadis S, Ravitz P. An approach to interpersonal psychotherapy for postpartum depression: focusing on interpersonal changes. Can Fam Physician 2007;53:1469-75.

50. O'Hara MW, Stuart S, Gorman LL, Wenzel A. Efficacy of interpersonal psychotherapy for postpartum depression. Arch Gen Psychiatry 2000;57:1039-45.

51. Favreliere S, Nourrisson A, Jaafari N, Perault Pochat MC. Treatment of depressed pregnant women by selective serotonin reuptake inhibitors: risk for the foetus ant the newborn. Encephale 2010;36(Suppl 2):133-8.

52. Diav-Citrin O, Ornoy A. Selective serotonin reuptake inhibitors in human pregnancy: to treat or not to treat? Obstet Gynecol Int 2012;698947.

53. Einarson A, Pistelli A, DeSantis M, Malm H, Paulus WD, Panchaud A, et al. Evaluation of the risk of congenital cardiovascular defects associated with use of paroxetine during pregnancy. Am J Psychiatry 2008; 165:749-52.

54. Alwan S, Reefhuis J, Rasmussen SA, Olney RS, Friedman JM. National Birth Defects Prevention Study. Use of selective serotonin-reuptake inhibitors in pregnancy and the risk of birth defects. N Engl J Med 2007;356:2684-92.

55. Suri R, Altshuler L, Hellemann G, Burt VK, Aquino A, Mintz J. Effects of antenatal depression and antidepressant treatment on gestational age at birth and risk of preterm birth. Am J Psychiatry 2007;164:1206-13.

56. Kallen B, Olausson PO. Maternal use of selective serotonin re-uptake inhibitors and persistent pulmonary hypertension of the newborn. Pharmacoepidemiol Drug Saf 2008;17:801-6.

57. Einarson A, Choi J, Koren G, Einarson T. Outcomes of infants exposed to multiple antidepressants during pregnancy: results of a cohort study. J Popul Ther Clin Pharmacol 2011;18:390-6.
58. Cole JA, Ephross SA, Cosmatos IS, Walker AM. Paroxetine in the first trimester and the prevelance of congenital malformations. Pharmacoepidemiol Drug Saf 2007;16:1075-85.

59. Einarson A, Pistelli A, DeSantis M, Malm H, Paulus WD, Panchaud A, et al. Evaluation of the risk of congenital cardiovascular defects associated with use of paroxetine during pregnancy. Am J Psychiatry 2008;165:749-52.

60. Pedersen LH, Henriksen TB, Vestergaard M, Olsen J, Bech BH. Selective serotonin reuptake inhibitors in pregnancy and congenital malformations: population based cohort study. BMJ 2009;339:3569.

61. Eberhard-Gran M, Eskild A, Opjordsmoen S. Treating mood disorders during pregnany: safety considerations. Drug Saf 2005;28:695-706.

62. Davis RL, Rubanowice D, McPhillips H, Raebel MA, Andrade SE, Smith D, et al. Risks of congenital malformations and perinatal events among infants exposed to antidepressant medications during pregnancy. Pharmacoepidemiol Drug Saf 2007;16:1086-94.

63. Leiknes KA, Cooke MJ, Jarosch-von Schweder L, Harboe I, Høie B. Electroconvulsive therapy during pregnancy: a systematic review of case studies. Arch Womens Ment Health 2015;18:1-39.

64. Miller LJ. Use of electroconvulsive therapy during pregnancy. Hosp Community Psychiatry 1994;45:444-50.

65. Bulbul F, Copoglu US, Alpak G, Unal A, Demir B, Tastan MF, et al. Electroconvulsive therapy in pregnant patients. Gen Hosp Psychiatry 2013;35:636-9.

66. Bulut M, Bez Y, Kaya MC, Copoglu US, Bulbul F, Savas HA. Electroconvulsive therapy for mood disorders in pregnancy. J ECT 2013;29:19-20.

67. Anderson EL, Reti IM. ECT in pregnancy: a review of the literature from 1941 to 2007. Psychosom Med 2009;71:235-42.

68. Apter G, Devouche E, Gratier M. Perinatal Mental Health. J Nerv Ment Dis 2011; 199:575-7.

\section{SUPPLEMENTS}

Supplement 1. Patient Health Questionnaire (PHQ-9)

Over the last 2 weeks, how often have you been bothered by any of the following
problems? $\begin{array}{ll}\text { Not Several More than } & \begin{array}{l}\text { Nearly all Days half the days every day } \\ \text { (Use " } " \text { " to indicate your answer) }\end{array}\end{array}$

1. Little interest or pleasure in doing things

2. Feeling down, depressed, hopeless

3. Trouble falling or staying asleep, or sleeping too much

4. Feeling tired or having little energy

5. Poor appetite or overeating

$\begin{array}{llll}0 & 1 & 2 & 3\end{array}$

$\begin{array}{llll}0 & 1 & 2 & 3\end{array}$

$\begin{array}{llll}0 & 1 & 2 & 3 \\ 0 & 1 & 2 & 3\end{array}$

6. Feeling bad about yourself-or that you are a failure or have let yourself or your family down

7. Trouble concentrating on things, such as reading the newspaper or watching television

$\begin{array}{llll}0 & 1 & 2 & 3\end{array}$

$\begin{array}{llll}0 & 1 & 2 & 3\end{array}$

8. Moving or speaking so slowly that other people could have noticed. Or the opposite onily down:2dgety or restless that you have been moving around a lot more than usual

9. Thoughts that you would be better off dead, or of hurting yourself

$0 \quad 1$

2

3

10. If you checked off any problems, how difficult have these problems made it for you to do your work, take care of things at home, or get along with other people?

Not difficult at all Somewhat difficult Very difficult Extremely difficult
$0+$
$+$
$+$ $=$ TOTAL SCORE: 
Total Score

\section{1-4}

5-9

10-14

15-19

20-27
Depression Severity

Minimal Depression

Mild Depression

Moderate Depression

Moderately severe depression

Severe depression

Supplement 2. Beck Depression Inventory

1- (0) I do not feel sad.

(1) I feel sad much of the time.

(2) I am sad all the time.

(3) I am so sad or unhappy that I can't stand it.

2- (0) I am not discouraged about my future.

(1) I feel more discouraged about my future than I used to be.

(2) I do not expect things to work out for me.

(3) I feel my future is hopeless and will only get worse.

3- (0) I do not feel like failure.

(1) I have failed more than I should have.

(2) As I look back, I see a lot of failures.

(3) I feel I am a total failure as a person.

4- (0) I get as much pleasure as I ever did from the things I enjoy.

(1) I donut enjoy things as much as I used to.

(2) I get very little pleasure from the things I used to enjoy.

(3) I can't get any pleasure from the things I used to enjoy

5- (0) I donot feel particularly guilty.

(1) I feel guilty over many things I have done or should have done.

(2) I feel quite guilty most of the time.

(3) I feel guilty all of the time.

6- (0) I donot feel I am being punished.

(1) I feel I may be punished.

(2) I expect to be punished.

(3) I feel I am being punished.

7- (0) I feel the same about myself as ever.

(1) I have lost confidence in myself.

(2) I am disappointed in myself.

(3) I dislike myself.

8- (0) I donot criticize or blame myself more than usual.

(1) I am more critical of myself than I used to be.

(2) I criticize myself for all of my faults.

(3) I blame myself for everything bad that happens. 
Supplement 2. Beck Depression Inventory

9- (0) I do not have any thoughts of killing myself.

(1) I have thoughts of killing myself, but I would not carry them out.

(2) I would like to kill myself.

(3) I would kill myself if I had the chance.

10- (0) I do not cry anymore than I used to.

(1) I cry more than I used to.

(2) I cry over every little thing.

(3) I feel like crying, but I can't.

11- (0) I am no more restless or wound up than usual.

(1) I feel more restless or wound up than usual.

(2) I am so restless or agitated that it's hard to stay still.

(3) I am so restless or agitated that I have to keep moving or doing something.

12- (0) I have not interest in other people or activities.

(1) I am less interested in other people or things than before.

(2) I have lost most of my interest in other people or things.

(3) It's hard to get interested in anything.

13- (0) I make decisions about as well as ever.

(1) I find it more difficult to make decisions than usual.

(2) I have much greater difficulty in making decisions than I used to.

(3) I have trouble making any decisions.

14- (0) I do not feel I am worthless.

(1) I do not consider myself as worthwhile and useful as I used to.

(2) I feel more worthless as compared to other people.

(3) I feel utterly worthless.

15- (0) I have as much energy as ever.

(1) I have less energy than I used to have.

(2) I do not have enough energy to do very much.

(3) I do not have enough energy to do anything.

16- (0) I have not experienced any change in my sleeping pattern.

(la) I sleep somewhat more than usual.

(1b) I sleep somewhat less than usual.

(2a) I sleep a lot more than usual.

(2b) I sleep a lot less than usual.

(3a) I sleep most of the day.

(3b) I wake up 1-2 hours early and can't get back to sleep. 
Supplement 2. Beck Depression Inventory

17- (0) I am no more irritable than usual.

(1) I am more irritable than usual.

(2) I am much more irritable than usual.

(3) I am irritable all the time.

18- (0) I have not experienced any change in my appetite.

(1a) My appetite is somewhat less than usual.

(1b) My appetite is somewhat greater than usual.

(2a) My appetite is much less than before.

(2b) My appetite is much greater than usual.

(3a) I have no appetite at all.

(3b) I crave food all the time.

19- (0) I can concentrate as well as ever.

(1) I can't concentrate as well as usual.

(2) It's hard to keep my mind on anything for very long.

(3) I find I can't concentrate on anything.

20- (0) I am no more tired or fatigued than usual.

(1) I get more tired or fatigued more easily than usual.

(2) I am too tired or fatigued to do a lot of the things I used to do.

(3) I am too tired or fatigued to do most of the things I used to do.

21- (0) I have not noticed any recent change in my interest an sex.

(1) I am less interested in sex than I used to be.

(2) I am much less interested in sex now.

(3) I have lost interest in sex completely.

Scoring: There is a four-point scale for each item ranging from 0 to 3 . On two items (16 and 18) there are seven options to indicate either an increase or decrease of appetite and sleep. Total score of 0-13 is considered minimal range, 14-19 is mild, 20-28 is moderate, and 29-63 is severe.

Supplement 3. Center for Epidemiologic Studies Depression (CES-D)

\begin{tabular}{|c|c|c|c|c|}
\hline $\begin{array}{l}\text { Below is a list of some ways you may have felt or behaved. Please indicate how } \\
\text { often you have felt this way during the last week by checking the appropriate space. } \\
\text { Please only provide one answer to each question. }\end{array}$ & $\begin{array}{l}\text { Rarely } \\
\text { (<1 day) }\end{array}$ & $\begin{array}{l}\text { Some } \\
\text { (1-2 day) }\end{array}$ & $\begin{array}{l}\text { Occasionally } \\
\text { (3-4 day) }\end{array}$ & $\begin{array}{l}\text { Most } \\
\text { (5-7 day) }\end{array}$ \\
\hline I didn't feel like eating; my appetite was poor. & o & o & o & o \\
\hline I felt that I couldn't shake off the blues even with help from my family or friends. & o & o & o & o \\
\hline I had trouble keeping my mind on what I was doing. & o & o & o & $\mathrm{o}$ \\
\hline I felt depressed. & o & o & o & o \\
\hline I felt that everything I did was an effort. & o & o & o & o \\
\hline I felt hopeful about the future. & o & o & o & o \\
\hline
\end{tabular}


Supplement 3. Center for Epidemiologic Studies Depression (CES-D)

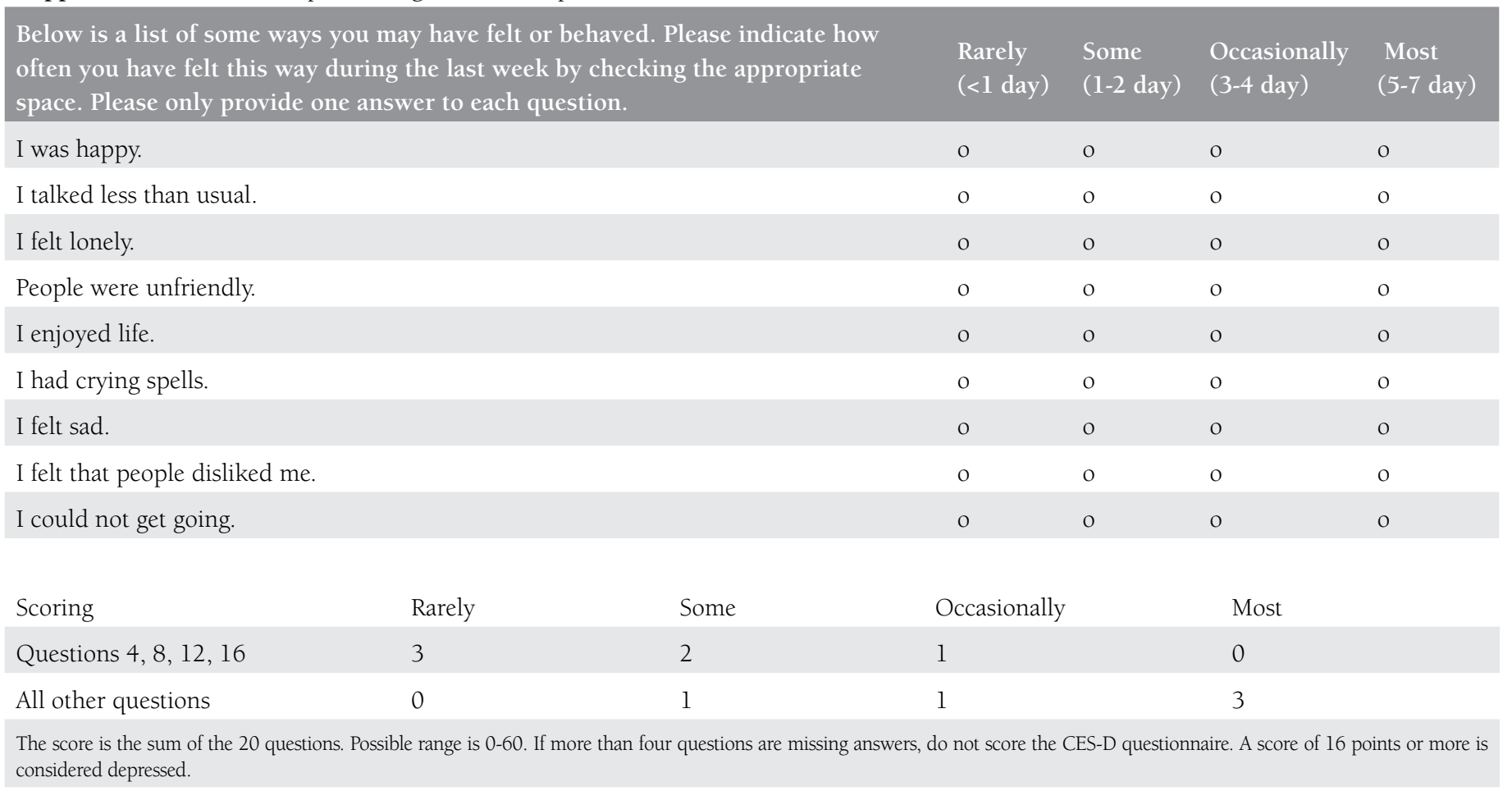

Supplement 4. Edinburgh Postnatal Depression Scale (EPDS)

As you are pregnant or have recently had a baby, we would like to know how you are feeling. Please check the answer that comes closest to how you have felt IN THE PAST 7 DAYS, not just how you feel today.

1. I have been able to laugh and see the funny side of things

---As much as I always could

---Not quite so much now

---Definitely not so much now

---Not at all

0

1

2

3

2. I have looked forward with enjoyment to things

---As much as I ever did

---Rather less than I used to

---Definitely less than I used to

---Hardly at all

3. I have blamed myself unnecessarily when things went wrong

---Yes, most of the time

---Yes, some of the time

---Not very often

---No, never

4. I have been anxious or worried for no good reason

---No, not at all

---Hardly ever

---Yes, sometimes

---Yes, very often

0
1
2
3

3

5. I have felt scared or panicky for no very good reason

---Yes, quite a lot

---Yes, sometimes

---No, not much

---No, not at all
3

2

1

0 
Supplement 4. Edinburgh Postnatal Depression Scale (EPDS)

As you are pregnant or have recently had a baby, we would like to know how you are feeling. Please check the answer that comes closest to how you have felt IN THE PAST 7 DAYS, not just how you feel today.

6. Things have been getting on top of me

---Yes, most of the time I haven't been able to cope at all 3

---Yes, sometimes I haven't been coping as well as usual 2

---No, most of the time I have coped quite well 1

---No, I have been coping as well as ever

0

7. I have been so unhappy that I have had difficulty sleeping

---Yes, most of the time

3

---Yes, sometimes

2

---Not very often

---No, not at all

0

8. I have felt sad

---Yes, most of the time

3

---Yes, quite often

2

---Not very often

1

---No, not at all

0

9. I have been so unhappy that I have been crying

---Yes, most of the time

3

---Yes, quite often

2

---Only occasionally

---No, never

.

10. The thought of harming myself has occurred

---Yes, quite often

3
2
1
0

times

---Hardly ever

---Never

0

Scoring: The score is the sum of the 10 questions. Possible range is 0-30. A score of 13 points or more is considered depressed. 